Biochimica et Biophysica Acta, 617 (1980) 76-84

(C) Elsevier/North-Holland Biomedical Press

BBA 57486

\title{
INCREASED SYNTHESIS OF PHOSPHATIDYLCHOLINE BY RAT LUNG FOLLOWING PREMATURE BIRTH
}

\author{
PAUL A. WEINHOLD, MARY M. QUADE, THERESE B. BROZOWSKI and \\ DOUGLAS A. FELDMAN \\ Veterans Administration Medical Center and Department of Biological Chemistry, University \\ of Michigan, Ann Arbor, MI 48105 (U.S.A.)
}

(Received June 13th, 1979)

Key words: Phosphatidylcholine synthesis; Lung surfactant; Premature birth; (Rat)

\section{Summary}

Pregnant rats were delivered prematurely at 20 days and 21 days gestation ( 2 and 1 day premature). The survival was $52 \pm 3 \%$ at 20 days gestation and $100 \%$ at 21 days gestation. $\left[\mathrm{Me}^{-14} \mathrm{C}\right] \mathrm{Choline}$ incorporation into phosphatidylcholine increased by $60 \%$ during the $3 \mathrm{~h}$ of survival after delivery at 20 days gestation. The increase in incorporation occurred during the first hour of survival. [Me${ }^{14} \mathrm{C}$ ]Choline incorporation also increased to a lesser extent following survival at 21 days gestation. The incorporation after $3 \mathrm{~h}$ of survival at 20 days and 21 days gestation was similar to that obtained with adult lung slices. The incorporation of $\left[\mathrm{U}_{-}{ }^{14} \mathrm{C}\right]$ glycerol, $\mathrm{D}-\left[\mathrm{U}-{ }^{14} \mathrm{C}\right]$ glucose, $\left[1-{ }^{14} \mathrm{C}\right]$ palmitate and $\left[1,2-{ }^{14} \mathrm{C}\right]-$ ethanolamine did not increase following delivery at either 20 days or 21 days gestation. The incorporation of ${ }^{33} \mathrm{PO}_{4}$ into phosphatidylcholine increased to the same relative extent as $\left[\mathrm{Me}^{-1}{ }^{14} \mathrm{C}\right]$ choline incorporation. $\mathrm{D}-\left[\mathrm{U}-{ }^{14} \mathrm{C}\right]$ Glucose incorporation into the fatty acid portion of phosphatidylcholine and triacylglycerols and oxidation to ${ }^{14} \mathrm{CO}_{2}$ decreased during the $3 \mathrm{~h}$ of survival. The pattern of $\mathrm{D}-\left[\mathrm{U}-{ }^{14} \mathrm{C}\right]$ glucose incorporation following survival at 20 and 21 days gestation is similar to that obtained with adult lung slices. Dexamethasone treatment of mothers at 17 and 18 days gestation caused $\left[\mathrm{Me}^{\left.1{ }^{14} \mathrm{C}\right] \text { choline }}\right.$ incorporation to increase to adult values at 20 days gestation but not at 19 days or 21 days. We conclude that an adaptive mechanism exists which produces specific biochemical changes in lung metabolism following premature birth. This mechanism is functional in the rat as early as 2 days prior to normal term. 


\section{Introduction}

A major factor in the development of respiratory distress syndrome is the inability of newborms to maintain sufficient surface-active material in the alveoli and terminal bronchioles $[1,2]$. The risk of developing respiratory distress is highly correlated with the degree of prematurity of the infant [3]. Survival depends, to some extent, upon the ability of the lung to synthesize and secrete dipalmitoyl phosphatidylcholine within the first 18-78 h after birth.

Numerous reports have appeared concerning the effects of hormones and drugs on the rate of lung maturation in utero [4]. Only a limited amount of information exists concerning the metabolic events that occur immediately following premature birth. Rooney et al. [5] have reported finding large increases in the total phospholipid and phosphatidylcholine content of lung lavage fluid, taken from newborn rabbits surviving $3 \mathrm{~h}$ after premature delivery. Barrett et al. [6] found significant increases in survival and the lavage fluid phosphatidylcholine content after premature birth, following administration of aminophylline to fetal rabbits during gestation.

Since our laboratory has accumulated and reported a wide variety of data on the metabolism of lung during gestation of the rat [7-11], we selected the rat as a model to study the metabolic events associated with the synthesis of phosphatidylcholine during survival after premature birth. In this report, we describe experiments which compare the rate and pattern of incorporation of various radioactive precursors into phosphatidylcholine of lung slices from fetal rats, taken immediately following premature birth and after $3 \mathrm{~h}$ of survival.

\section{Materials and Methods}

Premature delivery and care of newborn rats. Pregnant rats (Holtzman Co., sperm positive) werekilled by decapitation and the uterus containing the fetuses rapidly removed. The fetuse were removed from the uterus with the placenta attached and the umbilical cord was tied before cutting. Repeated pressure on the chest of the newborn was performed until the animal showed reflex opening and closing of the mouth. The newborn animals were weighed and immediately placed in a $35^{\circ} \mathrm{C}$ incubator which was continually flushed with water-saturated $95 \% \mathrm{O}_{2} / 5 \% \mathrm{CO}_{2}$. The time from initial killing of the mother to the placement of the newborn in the incubator was less than $5 \mathrm{~min}$. Although the gestation time was estimated to be within $12 \mathrm{~h}$, the age of the fetal rats was verified by comparing the absolute body weight with data reported by Sikov and Thomas [12]. Fetal rats that were used for non-surviving controls were killing by decapitation immediately after delivery. The lungs were dissected from the animal and placed in petri dishes on ice. Newborn animals that survived $3 \mathrm{~h}$ were killed by decapitation and the lungs removed. Only animals which were pink and exhibited reflex movements when touched were used for newborn survival experiments.

Tissue preparations and incubations. Lung slices were prepared with a StadieRiggs tissue slicer. Slices (150-200 mg wet weight) were incubated in $2.0 \mathrm{ml}$ of Trowells T-8 medium which contained either $\left[\mathrm{Me}-{ }^{14} \mathrm{C}\right]$ choline $(0.2 \mathrm{mM}, 10 \mathrm{Ci} /$ $\mu \mathrm{mol}),\left[\mathrm{U}^{14} \mathrm{C}\right]$ glycerol $(0.2 \mathrm{mM}, 5 \mathrm{Ci} / \mu \mathrm{mol}),\left[1-{ }^{14} \mathrm{C}\right]$ palmitate $(1.0 \mathrm{mM}, 2 \mathrm{Ci} /$ 
$\mu \mathrm{mol})$ or $\mathrm{NaH}_{2}^{33} \mathrm{PO}_{4}$. Incubation with $\mathrm{D}-\left[\mathrm{U}_{-}{ }^{14} \mathrm{C}\right]$ glucose used glucose-free, Trowells T-8 supplied by Grand Island Biological. D-[U- $\left.{ }^{14} \mathrm{C}\right]$ glucose was added at a concentration of $5 \mathrm{mM}(0.1 \mathrm{Ci} / \mu \mathrm{mol})$. All radioactive compounds were purchased from New England Nuclear. Palmitate was added as a complex with serum albumin at a ratio of 1.8 palmitate to albumin. The albumin-palmitate complex was made by overnight equilibration of the palmitate with fatty acidfree albumin (Sigma Chemical Co.). The tissue incubations were conducted at $37^{\circ} \mathrm{C}$ in an atmosphere of $95 \% \mathrm{O}_{2} / 5 \% \mathrm{CO}_{2} . \Lambda$ fter $1 \mathrm{~h}$ the slices and medium were transferred to ice-cold tubes and the slices separated from the medium by brief centrifugation. The slices were washed once by suspending in ice-cold saline followed by brief centrifugation. The tissue slices were homogenized in $6 \mathrm{ml}$ of chloroform/methanol $(2: 1, \mathrm{v} / \mathrm{v})$ and the lipid extracted as previously described [11]. The lipid was dissolved in chloroform, aliquots were removed for the determination of total radioactivity and lipid phosphorus [11]. The remainder was stored under nitrogen at $-40^{\circ} \mathrm{C}$ until used for further chromatographic analysis.

Lipid analysis. Aliquots of the lipid extracts were chromatographed on silica gel thin-layer plates (Analabs Incorp. Foxboro, MA). Phospholipids were separated in the solvent system chloroform/methanol/acetic acid/water (100 : $60: 16: 3, \mathrm{v} / \mathrm{v}$ ). Neutral lipids were separated in the solvent system, benzene/ diethyl ether/acetic acid/ethanol $(100: 80: 0.4: 4, \mathrm{v} / \mathrm{v})$. The distribution of radioactivity among the separated lipids was determined by scraping the areas on the thin-layer directly into $10 \mathrm{ml}$ of OCS scintillation fluid (Amersham Corp.) contained in a scintillation vial. Radioactivity was determined in a liquid scintillation counter. The remaining portion of the lipid extract was applied to a thin-layer plate and phosphatidylcholine was isolated after development in the phospholipid solvent system. Phosphatidylcholine was extracted from the silica gel as previously described [11]. Aliquots of the phosphatidylcholine were taken for lipid phosphorus analysis and for the measurement of radioactivity. The concentration of phosphatidylcholine was calculated by dividing the total radioactivity in phosphatidylcholine by the specific activity of the isolated phosphatidylcholine. Portions of the phosphatidylcholine from incubations that involved radioactive glucose, and glycerol were analyzed by transmethanolysis in order to determine the distribution of radioactivity between the fatty acid and glycerol parts of the molecule [13]. Disaturated phosphatidylcholine was separated from the total phosphatidylcholine by treating phosphatidylcholine with mercuric acetate [14] followed by thin-layer chromatography [15]. In some experiments the disaturated phosphatidylcholine was isolated by the osmium tetroxide method [16]. Both methods gave essentially the same results, however, the osmium tetroxide method was more reproducible. Both the mercuric acetate and osmium tetroxide methods were routinely monitored by determining the recovery of $\left[1,2-{ }^{14} \mathrm{C}\right]$ palmitoyl-snglycero-3-phosphocholine (New England Nuclear) added to phosphatidylcholine previously isolated from adult rat lung. The radioactivity was always recovered in the disaturated phosphatidylcholine fraction (90-95\% recovery).

Dexamethasone treatment. Pregnant rats were given dexamethasone sodium phosphate (Maurry Biological Co., Los Angeles, CA) by intraperitoneal injection ( $3 \mu \mathrm{g} / \mathrm{g}$ body weight) on day 17 and 18 of gestation. 


\section{Results}

\section{Phosphatidylcholine synthesis after premature birth}

The survival of newborn rats $3 \mathrm{~h}$ after premature delivery was $52 \pm 3 \%$ when delivered at 20 days gestation ( 2 day premature), and $100 \%$ when delivered at 21 days gestation ( 1 day premature). Fetuses delivered at 19 days gestation did not survive. In all experiments, animals that did not survive died within 15 min following delivery.

The incorporation per $\mathrm{g}$ lung of $\left[\mathrm{Me}^{14} \mathrm{C}\right]$ choline into phosphatidylcholine and dipalmitoylphosphatidylcholine increased by more than $60 \%$ during the $3 \mathrm{~h}$ of survival after delivery at 20 days gestation (Table I). The incorporation was the same as that obtained in the fetal lung at 21 days gestation, and in the adult lung. The incorporation also appeared to increase after the delivery at 21 days gestation, but the increase was less significant $(P<0.10)$ than the increase at 20 days $(P<0.001)$. No apparent change in the selectivity of choline incorporation into the disaturated species occurred, since the percent of the total radioactivity in the disaturated species was the same in lungs from newborm rats and from rats surviving $3 \mathrm{~h}$. The amount of total phospholipid and phosphatidylcholine both increased by $16 \%$ after $3 \mathrm{~h}$ of survival following premature delivery at 20 days gestation.

The increase in the ability of lung slices to incorporate $\left[\mathrm{Me}^{-14} \mathrm{C}\right]$ choline into total phosphatidylcholine following birth was rapid, with most of the increase occurring within the first hour after delivery (Fig. 1). On the other hand, the amount of phosphatidylcholine did not increase until $2 \mathrm{~h}$ following delivery. The incorporation into the disaturated species of phosphatidylcholine increased at a constant rate during the $3 \mathrm{~h}$ survival.

The incorporation of ${ }^{33} \mathrm{PO}_{4}$ into phosphatidylcholine increased to the same

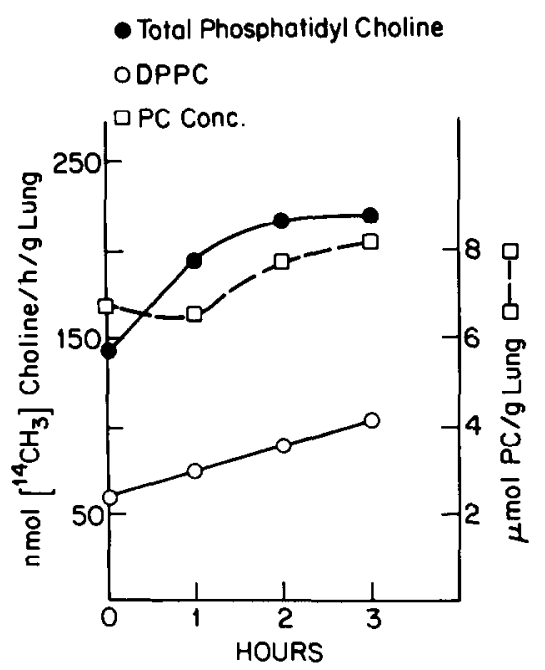

Fig. 1. Changes in the rate of $\left[\mathrm{Me}^{14} \mathrm{C}\right] \mathrm{choline}$ incorporation into phosphatidylcholine and dipalmitoylphosphatidylcholine and in phosphatidylcholine content following premature delivery at 20 days gestation. Each point is the average of triplicate incubations of slices from the lungs of 3-4 pups. 


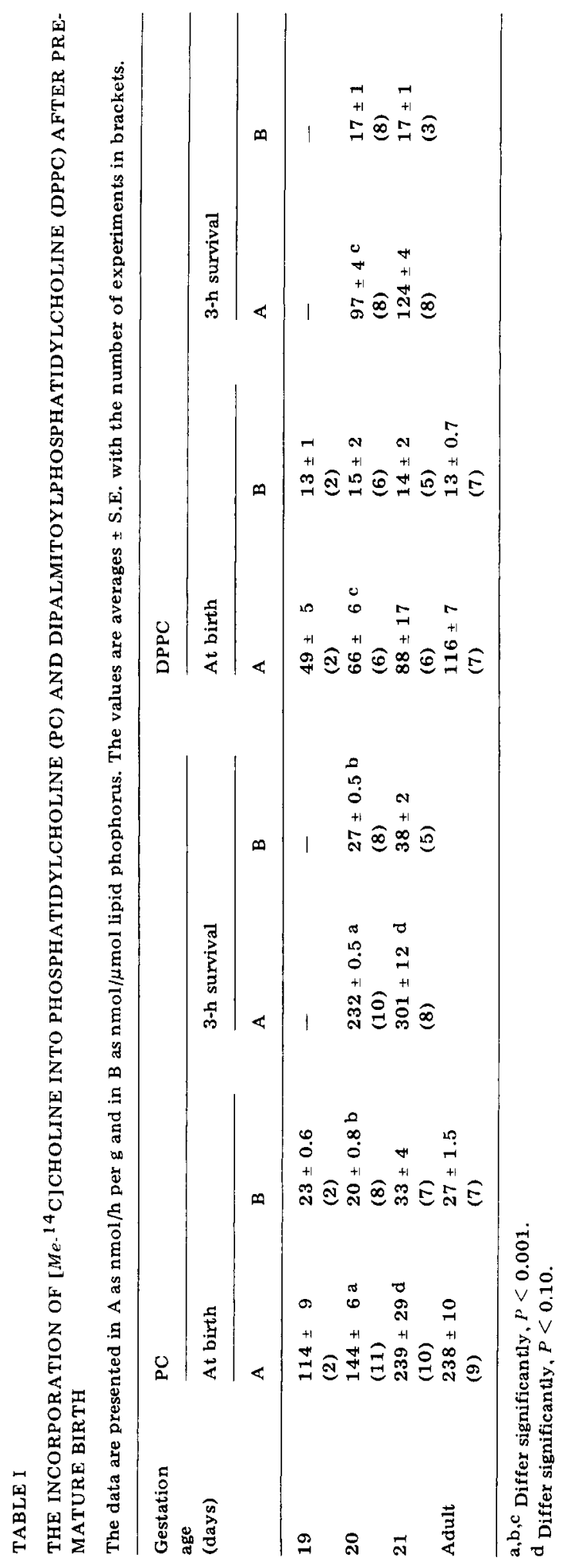


TABLE II

[U. ${ }^{14} \mathrm{C}$ ] GLUCOSE INCOPORATION INTO LIPIDS AND OXIDATION TO ${ }^{14} \mathrm{CO}_{2}$ BY LUNG SLICES FROM NEWBORN RATS PREMATURELY DELIVERED AT 20 DAYS AND 21 DAYS AND FROM ADULT

Values are the average $\mathrm{nmol} / \mathrm{h}$ per $\mathrm{g}$ lung $\pm \mathrm{S}$.E. for three experiments. PC, phosphatidylcholine; DPPC, dipalmito ylphosphatid ylcholine; and TG, triacylglycerol.

\begin{tabular}{|c|c|c|c|c|c|}
\hline \multirow[t]{2}{*}{ Product } & \multicolumn{2}{|l|}{20 days } & \multicolumn{2}{|l|}{21 days } & \multirow[t]{2}{*}{ Adult } \\
\hline & At birth & $+3 h$ & At birth & $+3 h$ & \\
\hline PC-glycerol & $78 \pm 5$ & $64 \pm 5$ & $70 \pm \quad 5$ & $76 \pm 12$ & $68 \pm 13$ \\
\hline PC-fatty acids & $118 \pm 15$ & $41 \pm 5$ & $74 \pm 16$ & $42 \pm 9$ & $44 \pm 17$ \\
\hline TG-glycerol & $39 \pm 6$ & $38 \pm 6$ & $68 \pm 6$ & $66 \pm 6$ & $33 \pm 6$ \\
\hline TG-fatty acid & $77 \pm 5$ & $49 \pm 7$ & $74 \pm 7$ & $47 \pm 8$ & $25 \pm 6$ \\
\hline${ }^{14} \mathrm{CO}_{2}$ & $1305 \pm 159$ & $664 \pm 96$ & $1080 \pm 109$ & $850 \pm 97$ & $1039 \pm 180$ \\
\hline DPPC & $123 \pm 14$ & $58 \pm 6$ & $85 \pm 17$ & $55 \pm 15$ & $50 \pm 12$ \\
\hline
\end{tabular}

relative extent as $\left[\mathrm{Me}^{14} \mathrm{C}\right]$ choline ( $69 \pm 6$ at birth, $106 \pm 13$ after $3 \mathrm{~h}$ survival). This result suggests that increased choline transport is not responsible for the increased incorporation. The incorporation of $\left[\mathrm{U}-{ }^{14} \mathrm{C}\right]$ glycerol, $\left[\mathrm{U}-{ }^{14} \mathrm{C}\right]$ glucose, $\left[1,2-{ }^{14} \mathrm{C}\right]$ ethanolamine, and $\left[1-{ }^{14} \mathrm{C}\right]$ palmitate did not increase.

A detailed study of the changes in glucose incorporation following premature delivery at 20 days and 21 days gestation clearly shows that the metabolism of glucose is significantly altered (Table II). The incorporation of $\left[\mathrm{U}-{ }^{14} \mathrm{C}\right]$ glucose in to phosphatidylcholine and triacylglycerols decreased after $3 \mathrm{~h}$ of survival at 20 days gestation. The major decrease occurred in the fatty acid portion of the molecule. The decreased rate of $\left[\mathrm{U}-{ }^{14} \mathrm{C}\right]$ glucose incorporation into dipalmitoylphosphatidylcholine parallels that for the total phosphatidylcholine. Phosphatidylcholine accounted for about $50 \%$ of the $\left[\mathrm{U}-{ }^{14} \mathrm{C}\right]-$ glucose radioactivity incorporated into total lipid. The second highest incorporation was found in triacylglycerol $(30 \%)$. The oxidation of $\left[\mathrm{U}-{ }^{14} \mathrm{C}\right]$ glucose to ${ }^{14} \mathrm{CO}_{2}$ decreased by $40 \%$ after $3 \mathrm{~h}$ of survival at 20 days gestation. The pattern of changes in glucose metabolism at 21 days gestation was similar to that found at 20 days gestation, only the changes were less dramatic. The pattern of [U $-{ }^{14} \mathrm{C}$ ]glucose incorporation obtained $3 \mathrm{~h}$ after delivery at 20 and 21 days gestation, is identical to that found in adult lung.

Effect of dexamethasone treatment on the synthesis of phosphatidylcholine by fetal lung slices

Dexamethasone treatment of the mothers at 17 and 18 days gestation resulted in an increased ability of lung slices to incorporate $\left[\mathrm{Me}^{-14} \mathrm{C}\right]$ choline into phosphatidylcholine at 20 days gestation but not at 19 days or 21 days (Table III). The rate of incorporation in 20 days gestation fetuses from dexamethasone-treated mothers approached the rate observed for adult lung and fetal lung at 21 days gestation. Thus, an apparent acceleration of the normal developmental process occurred. Interestingly, the incorporation of $\left[\mathrm{U}^{14} \mathrm{C}\right]-$ glucose and $\left[1-{ }^{14} \mathrm{C}\right]$ palmitate did not increase in the 20-day-old fetuses from dexamethasone-treated mothers. This observed increase in choline incorporation without a corresponding increase in labeling of the diacylglycerol portion 
TABLE III

THE EFFECT OF DEXAMETHASONE TREATMENT OF THE MOTHER ON THE INCORPORATION OF RADIOACTIVE PKECUKSORS IN'TU PHOSPHATIDYLCHOLINE BY LUNG SLICES FROM FETAL AND ADULT RATS

The glucose concentration was $2.0 \mathrm{mM}$. Each experiment used the litter from one pregnant rat and the slice incubations were done in triplicate. The data are the average $\mathrm{nmol} / \mathrm{h}$ per $\mathrm{g} \pm \mathrm{S}$.E. with the number of experiments in brackets. Dex., dexamethasone treated.

\begin{tabular}{|c|c|c|c|c|c|c|}
\hline \multirow{2}{*}{$\begin{array}{l}\text { Gestation } \\
\text { age } \\
\text { (days) }\end{array}$} & \multicolumn{2}{|c|}{$\left[M e^{14} \mathrm{C}\right]$ choline } & \multicolumn{2}{|c|}{$\left[\mathrm{U}-{ }^{14} \mathrm{C}\right] \mathrm{Glucose}$} & \multicolumn{2}{|c|}{$\left[1-{ }^{14} \mathrm{C}\right]$ Palmitate } \\
\hline & Control & Dex. & Control & Dex. & Control & Dex. \\
\hline 19 & $\begin{array}{l}111 \pm 7 \\
(4)\end{array}$ & $\begin{array}{l}120 \pm 4 \\
(3)\end{array}$ & $\begin{array}{l}37 \pm 8 \\
(4)\end{array}$ & $\begin{array}{l}34 \pm 2 \\
(4)\end{array}$ & - & - \\
\hline 20 & $\begin{array}{l}157 \pm 14^{a} \\
(18)\end{array}$ & $\begin{array}{l}236 \pm 14 a \\
(11)\end{array}$ & $\begin{array}{l}57 \pm 16 \\
(4)\end{array}$ & $\begin{array}{l}47+5 \\
(4)\end{array}$ & $\begin{array}{l}407 \pm 78 \\
(13)\end{array}$ & $\begin{array}{l}385 \pm 73 \\
(10)\end{array}$ \\
\hline 21 & $\begin{array}{l}287 \pm 32 \\
(7)\end{array}$ & $\begin{array}{l}293 \pm 16 \\
(4)\end{array}$ & $\begin{array}{l}88 \pm 25 \\
(4)\end{array}$ & $\begin{array}{l}87 \pm 17 \\
(4)\end{array}$ & $\begin{array}{l}378 \pm 19 \\
(6)\end{array}$ & $\begin{array}{l}350 \pm 20 \\
(6)\end{array}$ \\
\hline Adult & $\begin{array}{l}274 \pm 12 \\
(19)\end{array}$ & & $\begin{array}{l}79 \pm 28 \\
(12)\end{array}$ & & $\begin{array}{l}324 \pm 21 \\
(6)\end{array}$ & \\
\hline
\end{tabular}

a Significant difference, $P<0.001$.

of the molecule is similar to the results obtained following premature delivery at 20 days gestation.

\section{Discussion}

In the fetal rat lung, $\left[\mathrm{Me}^{14} \mathrm{C}\right]$ choline incorporation into phosphatidylcholine increases after the 19th day of gestation and reaches adult levels just before birth at 22 days [10]. We have observed increases in the rate of choline incorporation into phosphatidylcholine within hours after birth following premature delivery at 20 days gestation. Similar increases in choline incorporation can occur in utero, however, an additional $24-30 \mathrm{~h}$ gestation is required. Dexamethasone produces at $50 \%$ increase in choline incorporation at 20 days gestation, after injection of the mother at 17 and 18 days gestation. Thus at 20 days gestation, the regulatory mechanism which produces increased synthesis of phosphatidylcholine is fully developed and only requires the proper inilialion to be functional. The increase appears to specifically involve the choline pathway since the incorporation of other lipid precursors did not increase.

The administration of glucocorticoids to rats has been reported to accelerate maturation when assessed by morphological, physiological, and biochemical criteria [17-19]. Glucocorticoids generally require $24-48 \mathrm{~h}$ to produce changes in fetal lung. Aminophylline has been reported to enhance lung maturation [20] and to exert its effect within $3 \mathrm{~h}$ [21]. Thus, the rapid increase in choline incorporation following premature birth at 20 days gestation is more compatible with a regulatory mechanism mediated by cyclic AMP. A more definitive conclusion requires further biochemical analysis.

The lack of an observed increase in the incorporations of glucose, glycerol, and palmitate into phosphatidylcholine is surprising when compared to the observed increase in phosphatidylcholine concentration following premature 
birth. The results suggest that the diacylglycerol requirement is not met by de novo synthesis within the lung tissue. Instead the diacylglycerol may be derived from lipids stored in the lung and/or transported to the lung during the $3 \mathrm{~h}$ survival period. Hamosh et al. [22] reported that blood triacylglycerol levels increase sharply after normal delivery and high lipoprotein lipase activity exists in fetal rat lung at 20 and 21 days gestation. However, Cryer and Jones [23] reported low lipoprotein lipase activity prior to birth and a large increase immediately after birth. The ability of lung to produce increased amounts of phosphatidylcholine immediately following premature birth may depend upon both an increased activity of the pathway for de novo synthesis of phosphatidylcholine and an increase in the amount of diacylglycerol produced by lipoprotein lipase from lipids supplied by the serum and/or stored in the lung.

Slices from adult lung were previously reported to incorporate radioactivity from $\left[\mathrm{U}_{-}{ }^{14} \mathrm{C}\right.$ ]glucose into both the glycerol and fatty acid portions of phospholipids [24]. The incorporation of radioactivity into fatty acid is susceptible to changes in the metabolic conditions of the tissue. The ability of lung slices to incorporate $\left[\mathrm{U}-{ }^{14} \mathrm{C}\right.$ ]glucose into fatty acids is significantly decreased by prior starvation of the animal [25], storage of the slices in chilled buffer prior to incubation [25], and by increased fatty acids in the incubation media [26]. Increased concentrations of $\mathrm{CO}_{2}$ in lung perfusion experiments also produces a decrease in the incorporation of radioactive glucose into fatty acids [27]. The decrease in the incorporation of $\left[U \cdot{ }^{14} \mathrm{C}\right]$ glucose into fatty acids of phosphatidylcholine and triacylglycerol following premature delivery is consistent with the previous observations and further emphasizes that the utilization of glucose for fatty acid synthesis in lung is subject to sensitive regulation. Recent studies by Perez-Diaz et al. [28] suggest that glucose entry into the lung cells may be the rate-limiting step in glucose metabolism. The drop in glucose incorporation into phosphatidylcholine may be partially due to decreased transport. However, since the decrease is not uniformly reflected in both the glycerol and fatty acid portions of the molecule, glucose transport cannot account for all of the decreased metabolism.

Yeager and Hicks [29] reported that glucose uptake and oxidation to $\mathrm{CO}_{2}$ by lung slices from rats at 22 days gestation was similar to adult values. More recently, Hamosh et al. [30] concluded that glucose uptake, lactate production, and the incorporation of radioactive glucose into lipid was higher in fetal lung than at all other ages. Our results support the latter observations.

\section{Acknowledgements}

This work was supported by the Veterans Administration and by Grant HD02871 from the National Institute of Child Health and Human Development.

\section{References}

1 Avery, M. and Mead, J. (1959) Am. J. Dis. Child 97, 517-523

2 Farrell, P.M. and Avery, M.E. (1975) Am. Rev. Respir. Dis. 111, 657-688

3 Usher, R.H., Allen, A.C. and MeLean, F.H. (1971) Am. J. Obstet. Gynecol. 111, 826-832 
4 Taeusch, H.W. and Avery, M.E. (1977) in Development of the Lung (Hodson, W.A., ed.), pp. 399 418, Marcel Dekker, New York

5 Rooney, S.A., Gobran, L.I. and Wai-Lee, T.S. (1977) J. Clin. Invest. 60, 754-759

6 Barrett, C.T., Sevanian, A., Phelps, D.L., Gilden, C, and Kaplan, S.A. (1978) Pediatr. Res. $12,38-42$

7 Feldman, D.A., Kovac, C.R., Dranginis, P.L. and Weinhold, P.A. (1978) J. Biol. Chem, 253, 4980-4986

8 Ravinuthala, H.R., Miller, J.C. and Weinhold, P.A. (1978) Biochim. Biophys. Acta 530, $347-356$

9 Stern, W., Kovac, C. and Weinhold, P.A. (1976) Biochim. Biophys. Acta 441, $280-293$

10 Weinhold, P.A. (1968) J. Lipid Res. 9, 262-266

11 Weinhold, P.A, and Villee, C.A. (1965) Biochim. Biophys. Acta 106, 540-550

12 Sikov, M.R. and Thomas, J.M. (1970) Growth 34, 1-14

13 Tarlov, A.R. and Kennedy, E.P. (1965) J. Biol. Chem. 240, 49-53

14 King, R.J. and Clements, J.A. (1970) J. Lipid Res. 11, 381-385

15 Mason, R.J., Ilubor, G. and Vaughan, M. (1972) J. Clin. Invest. 51, $68-73$

16 Mason, R.J., Nellenbogen, J. and Clements, J.A. (1976) J. Lipid Res. 17, 281--284

17 Gilden, C.A., Sevanian, D.F., Tierney, D.F., Kaplan, S.A. and Barrett, C.T. (1977) Pediatr. Res. 11. $845-848$

18 Ballard, P.L. (1977) Fed. Proc. 36, 2660-2665

19 Kauffman, S.L. (1977) Lab. Invest. 36, 395-401

20 Cobet, A.J., Flax, P., Alston, C, and Rudolph, A.J. (1978) Pediatr. Res. 12, 797-799

21 Milkovic, S., Milkovic, K. and Paunovic, I. (1973) Fndocrinology 92, $380 \quad 385$

22 Hamosh, M., Simon, M.R., Cantor, H. and Hamosh, P. (1978) Pediatr. Res. 12, 1132--1136

23 Cryer, A. and Jones, H.M. (1978) Biochem. J. 174, 447-451

24 Tierney, D.F. and Levy, S.E. (1976) in The Biochemical Basis of Pulmonary Function (Crystal, R.G., ed.), pp. 105-125, Marcel Dekker, New York

25 Scholz, R.W. and Rhoades, R.A. (1971) Biochem. J. 124, 257-264

26 Salisburg-Murphy, S., Rubinstein, D. and Beck, J.C. (1966) Am. J. Physiol. 211, $988-992$

27 Longmore. W.J. and Mourning. J.T. (1977) J. Lipid Res. 18, 309-313

28 Perez-Diaz, J., Martin-Requero, A., Ayuso-Parrilla, M.S. and Parrilla, R. (1977) Am. J. Physiol. 232, E394-E400

29 Yeager, H. and Hicks, P.S. (1972) Proc. Soc. Exp. Biol. Med. 141, 1-3

30 Hamosh, M.Y., Shechter, P. and Hamosh, P. (1978) Pediatr. Res. 12, 95-100 